\title{
The European Union and the Police of the EU Member States in the Beginning of the 21st Century: Some Results and Prospects
}

\author{
Tatyana Victorovna Vorotilina*, Oleg Nikolayevich Lauta, Lyudmila Anatolyevna Popova, \\ Yevgeniy Anatolyevich Pervyshov and Anatoliy Kirillovich Kiselyov
}

\author{
North-Caucasus Federal University, Russian Federation; vorotilina@mail.ru
}

\begin{abstract}
Some results of the European Union development over the last decade are considered. At this background the organization of the police activities in the EU member states to engage the non-governmental non-commercial organizations, other community structures in combating crime in Europe is analyzed. At that, the basic objective of the EU countries police cooperation is ensuring the high level of personal protection and security for the European citizens. Some new crime prevention approaches of the police in the EU member states, particularly, "community policing", "neighbor policing", etc., are analyzed. Special characteristics and national specific features of criminal policy and of the sphere of the transnational organized crime prevention in several European states are studied. The study involved multiple and diverse information sources, including, primarily, normative legal documents of the European Union and of its governing structures, guidelines on the police functioning both in the European Union as a hole and in its particular member states. The legal normative documents of another European body, namely, of the Council of Europe are analyzed as well. Also, some results and prospects of international cooperation within the EU framework and beyond to overcome both national and transnational crime are considered.
\end{abstract}

Keywords: Community, Crime, Governing System, International Cooperation, Non-Governmental Non-Commercial Organizations, Police, The European Commission, The European Union

\section{Introduction}

In 2013 a "Eurobarometer" study, undertaken by the European Commission, demonstrated practically overwhelming growth of disappointment in the EU. For instance, in 2007 in Spain 65\% of the interviewees expressed their trust in the EU, 23\% responded that they do not trust in the EU. Today, by the beginning of 2016, the situation has changed drastically: 20\% still support the EU, whilst $72 \%$ of the respondents are of the opposite opinion. Similar figures have been obtained in Greece, Portugal, Ireland, as well as in Hungary and Romania. Similar, though not so drastic, changes are characteristic even for the most successful UE members, including Germany, Austria and
Finland. In Great Britain, where over a long period of time the lowest level of the European Union support has been demonstrated by the community, the attitude to it now became even more hostile. This has been revealed most vividly in 2015, when hundreds of thousands of illegal immigrants overflowed the roads, frontier check-points and refugee asylums all over Europe. This also has been manifested, when the Europeans felt their insecurity, being protected neither by police nor by other security services (Charlie Hebdo editorial staff shooting, serial terror attacks in Paris on November, 13, 2015). This also became visible as several referendums on so-called "local sovereignty" were held in European countries, for example, in Scotland (Great Britain), Catalonia (Spain).

\footnotetext{
* Author for correspondence
} 
Taking all this into account, it stands to reason that a short analysis of the situation in the European Union itself and in the police of its member countries is an urgent task for scientists and politicians today.

\section{Method}

In the process of studying the subject matter of this article many traditional theoretical and methodological principles have been applied. They stimulated the authors not to just analyze the formal contents of the texts, but to deconstruct them, "to get deep inside the internal sense of the materials they deal with".

The authors follow the scientific principles of historism, the systematic structural approach and objectiveness, based on recognizing the objective determinism of the mass-character social phenomena, on the one hand, and the variability of the historical and law processes on the other hand.

The comparative-law method, having become the basic one in the presented study, afforded establishing general and specific components of police work, connecting the development of the law protection cooperation practice in the EU with the dynamics of the integration processes in economic and political sectors and also with the stages of modifying the interaction between economic integration and social development, identified in the EU history; the historical-genetic method was applied to determine the steady trends in the sphere of interaction between the state power, represented by the police, and the components of civil community, represented by mass-media, union trades, NGO, national and ethnical communities. By applying the method of retrospectivelogical reconstruction it became possible, in particular, to recreate the mental picture of the surrounding reality, intrinsic to the population of Europe.

The content-analysis method was used for studying the aggregate of the EU treaties, the normative sources, the official documents, expert estimates and analytical materials on the issue, as well as for statistical data analysis.

\section{History of the Issue}

The authors used current European documented sources on studying the development of police activities in the EU countries over the second half of the 20th till the beginning of the 21st centuries. The first group of the sources consists of the UN and the EU documents, international and European legislation on the police operations. An original source is the analysis of the guidance documents of the European Police College (CEPOL) since 2001 through 2014. Among other documents of the EU authorities some decisions of the European Commission have been studied. The second group of the sources consists of national legislation of the European Union member states, as well as of the departmental normative legal instruments of all-national and regional levels. Those are, of course, the national police codes of ethics, Police Laws (with different options of their proper names), documents of the national police academies, institutes and colleges. The third group is represented by the materials of the domestic and foreign periodical press.

The literature on the subject matter of the study is diverse in its content and unequal in its scientific value. Within domestic historiography the foreign police have not been paid any considerable attention. At the frontier of the 20-21 centuries the experts in different sectors of science reveal greater interest in the European Union integration processes.

One of the first approaches in studying the integration process proved to be so-called intergovernmental approach. The second leading trend in studying the European integration abroad becomes "federalism". The adherents of this school believe that the states, which joined the EU, sacrifice a part of their national prerogatives, including the refusal from some separate segments of the national interests to the benefit of the common European integration structures. At that, gradually, depending on the degree of the integration, the authority of the integration organs increases as the power authority of the national governments decreases. The final result of the European integration, according to "federalists", will be the creation of a federal state based on the EU.

Great attention has been paid lately by the foreign authors to the EU role in strengthening the overall European security. However, here the European authors are traditionally divided in "Europeists" and "Atlanticists". French school of history and political science, beginning from the period of the Fifth Republic, has been adhering to "Europeism" positions, having imbibed the ideas of Gaullism.

In the European scientific world in the end of the 20th century the number of studies on the issues of the police activity have considerably increased, applying the critical 
approach, based on the liberal or even radical values. One of those studies suggested that the role of the police in western society should be analyzed in light of the class conflict, others considered that the police should be accountable to and controlled by the community.

Large majority of the European studies hardly apply any retrospective analysis of the police forces development trends. Some exceptions are the monographs by ${ }^{1-4}$, where the above mentioned issues are reflected, though, not in full.

Notwithstanding this negative aspect, it should be highlighted that the European scientists and practitioners in the end of the 20th and in the beginning of the 21st centuries have made considerable contribution in studying theoretical and organizational problems of the police. In the monographs and articles of European scientists the theoretical issues of European and international police science are investigated quite widely and profoundly $\mathrm{y}^{5-11}$. European police science is, to a larger degree, pragmatically orientated. This can be easily explained, given the fact that most of the European Union states had adopted official and scientific understanding of the social role of the police and other state institutions as early as 70-80s.

Before the 90 s of the last century the attention of the foreign police scientists has been, to a large degree, concentrated on studying separate aspects of the police activity. Investigations of the integration processes in the police education sector were left unnoticed. Western scientists were busy creating theoretical concepts and practical recommendations on a number of urgent issues of law enforcement.

The priority trends of the published works, issued in the USA and in so-called "old" EU countries, were the organizational foundations for separate police departments and services functions.

It is in the USA, basically, that the history of the police was developed extensively in the end of the twentieth century. And, though the American scientists paid much greater attention to studying the history of the police in the USA, they could not help being tempted to constantly compare it with the European police development history ${ }^{12,13}$. This was, however, quite natural, as far as the roots of the police, and of American police, particularly, are placed in the history of European continent.

The considerable generalizing study on social aspects of the police activity has been issued in the beginning of the 90 s by $^{14}$. The authorship of some definitions, terms, now applied widely in the history of police science, belongs to him. Here, for example, so-called "social" definition of the police: "Police is a social system, which is itself a part of some community institutions, encompassing the whole legal system and the system of justice. Social system can depend on current social relationships between personalities or groups. Ideally, the community systems bring mutual harmony to those institutions. However, the social systems are based on the actions of the human beings". ${ }^{14}$ Such a definition corresponds to the idea of "social dimension", put forth today by Russian scientists from Institute of Europe of the Russian Academy of Sciences. B. Berg ${ }^{15}$ is also the author of the detailed comparative analysis of such social aspects of the police operations in $70-80 \mathrm{~s}$ of the $20^{\text {th }}$ century as gender and national policy in the police, better known in Europe as multiculturalism policy since the first decade of the 21st century.

When analyzing so-called national component of the police service in the USA and in some of the European countries, the American researchers highlight the growth of racial and national toleration in the police structures over 60-90s as regards the representatives of the "colored" population within the police stations, especially in megalopolises and in places where the "non-titular" nations live closely together ${ }^{16-22}$.

A difficult problem in foreign historiography is the correlation of national and common European component in identifying the status of the policemen and in determining their relationships with the community. In this regard some interesting studies have been undertaken ${ }^{23-25}$.

Notwithstanding the contribution by the above mentioned researchers to studying the specified problem, there is still a necessity to develop it further. This is explained by the dynamic development of modern international relations, associated with permanent transformation of the international institutions, by the urgency of the internal security problems in every EU member state and in the European Union as a whole, by ethnical and religious conflicts, by permanent terror threats and attacks, as well as by other criminal challenges faced by the European community.

Characteristically, studying the activity of the police in a standalone country, the European scientists hardly reveal any interest in comparative methods of research, without ever taking into account the police structures even of the neighboring countries. It should be noted 
that the European police science is, to a large degree, pragmatically orientated. This can be easily explained, given the fact that in most European countries the official and scientific understanding of the social role of the police and other state institutions were adopted as early as $70-80$ s.

Not with standing the contribution by a number of researchers in studying the above mentioned problem, there is still a necessity for its further development.

\section{Discussion}

The United Europe is so far (and, it can be hoped, will remain, to a larger degree, in future) one of the bases of the new world order. However, the way to its creation was long and hard. Over the centuries the European states have not been united by some unity of aspirations and values, but rather they used to quarrel and be at war with each other. In a lapse of millennia of the human history close to 15 thousand wars have been waged ( 3 wars each year on average). In the 20th century in circa 500 wars and armed hostilities almost 100 million of men died ${ }^{26}$.

The start of the cooperation between separate police organizations at an international level was given by International Criminal Police Congress in $1914^{27}$. Then three decades of the two world wars with an in-between period followed.

Not with standing the following half-century history of European integration, the EU countries have not started implementing the common law-and-order policy immediately. Not earlier than in the beginning of the 90 s of the $20^{\text {th }}$ century the EU countries approached the development of this problem. Thus, in the Treaty on European Union a section "Principles of cooperation of the police authorities and the judicial authorities in criminal sphere" was included which envisaged three directions for intergovernmental cooperation of the member states ${ }^{28}$.

Thus, it can be presumed, that the history of the EU police started in the 90 s of the $20^{\text {th }}$ century.

The objective of the European Union from the moment of its creation was the aspiration to reconcile the economic achievements with the social development ${ }^{28}$. And this development, safe and secure for the citizens, was ensured and is being ensured still, mostly, by the internal police structures of each of the countries of the European Union. At the same time, it is understood, a priori, that without the feeling of personal safety and security no social model could be formed. Therefore, all the latest big agreements within the EU pay special attention to the issues of internal security, enforced, basically, by the police.

The differences in the principles and norms of the national legal systems, still present today, sometimes create serious obstacles for international relations. Eliminating such obstacles is now becoming one of the urgent tasks. Coordination in law enforcement and in law-and-order policies is implemented at both national and international levels ${ }^{29}$.

The increase of crime over the last decades objectively requires that the counteraction to it should be international. Such internalization is particularly observed in universalizing the police activities. In the Treaties of the European Union this sphere of cooperation is called "the cooperation between the police authorities and the judicial authorities in criminal and legal sphere". The documents of the Community establish a special role of the police and the judicial authorities' cooperation in criminal and legal sphere in the EU integration system, creating the so-called "third pillar" of the Union.

However, it should be noted that the tasks of the communal security in the countries of the European Union are characterized by the distributed responsibility among the bodies of the state power, public associations, business-structures and citizens.

Within the last decades the police authorities in EU countries are the objects of qualitative transformations, the essence of which lies in the processes, identified as the police socialization. Police socialization is a stage-bystage process of transforming the police from being a lawand-order authority, which essential attribute consists of employing the lawful means of enforcement, into a socially-oriented organ and a professional body, rendering services in the sector of public order and security. Three basic stages can be identified in socialization development.

The first stage covers $60-70$ s of the last century. It is characterized by the organizational formation of the effective political and civilian control over the police by dividing the functions of political and strategic management and those of administrative management in the police bodies. Strategic and political management came to be concentrated in a civilian body, namely, in the governmental department with special competence (ministry of internal affairs, ministry of justice, ministry of regional development), which activity was put under direct public and civilian control. Administrative management of the police was entrusted to the specially established collective or individual controlling authorities, 
accountable to the governmental department with special competence that is to civilian authorities.

The second stage covers the 80s up to the beginning of the 90s of the 20th century and is characterized by the inception and by the practical implementation of so-called "community policing" principles, the approach which could also be translated word for word as "public control" or "public police". Its essence consists of organizing the activities of the police in close contact with the population. This approach resulted in the phenomenon, defined as the partnership between the police, the community and the citizens.

The third stage started since the 90s and lasts up to now. Within this period serious structural and institutional alterations in the police bodies take place in all EU countries, especially, in East-European countries. The de-monopolization of the police functions in the sector of public security and public order occurs, associated with the police bodies specialization and differentiation (traffic police, criminal police, etc.), as well as the partial delegation of some competences to other bodies and departments (drug combating, terror prevention departments etc $)^{30}$. The specialization resulted in perceiving the police not as a military or law-and-order protection institution, but as a state body, which activity is associated with rendering comprehensive assistance and services to the law-abiding citizens in the sector of public security and order. Thus, the accent shifted from the physical counteraction to crime, requiring the wide application of the lawful means of enforcement, to crime prevention, envisaging close contact with community.

Given the scale of European integration, the processes of the internal affairs authorities' socialization acquired universal character in all European countries.

Ensuring the public order and security is the direct responsibility of the police, but every citizen and every official is obliged to assist and facilitate this process for the police. Such understanding is the direct result of implementing the partnership principles in the police organization and activities. The partnership between the police and the citizens is the essence and the contents of the EU police operations today. For several decades already the governing institutions in $\mathrm{EU}$ have been working to form the "Europe for citizens" where the non-governmental organizations express solidarity, where the new forms of social partnership come to life. Keeping abreast with the times the EU started applying the strategic planning in different sectors, including social sphere and crime, especially transnational crime, combating sector. It positions itself as a "network state", this idea including the network principle management and the creation of the network-built structures to solve global issues, particularly, the issues of combating crime.

At the same time, one of the most important features of modern democratic states is the agreement between the government and the citizens: In exchange for partial limitation of some civilian and personal freedoms the government is obliged to protect all community and all citizens. This legal protection is carried out by the police, which safeguards the order and fulfills the laws. Therefore, the residents of the European countries are loyal to the police, supporting it by word and by deed, and, more importantly, by taxes.

At that, the EU suffers from lack of democracy and of the effective leaders simultaneously. Three basis organs of the Union are the European Commission, the Council of Europe and the European Parliament. Technically, the European Commission is in charge for adopting plans, projects and policy of the European Union as a whole. The decisions on the proposals, submitted by the Commission, are made by the Council of Europe and by the European Parliament: This process is often a very lengthy one and does not always bring about positive results. The leaders of the EU member states and the leaders of the big countries in the first place often try to run after two hares. They declare their common European interests but, in fact, the interests of a definite state are of paramount importance for them.

The orientation of the citizens to the understanding that their security is in their own hands facilitated developing the public initiative: The people started uniting for mutual support in counteracting crime.

In the beginning of the 80s, when there was a strong hope, that the crime could be coped with by the professionals, if they were properly equipped and trained, the practice proved that the police staff increase brought about no positive results. The hopes that they would be omnipresent and efficient also proved to be far-fetched ${ }^{31}$. And then the public structures, dealing with crime control, came to life again. Among such structures the nongovernmental public organizations were notable ${ }^{32}$. The contribution of the Non-Governmental Organizations (NGO) into the law-and-order protection functions is implemented through the complex of extremely varied types of activity, from acting a part of the information communication link between different segments of society 
and the bodies of state power, to promoting the changes in legislation and in the state policy, to developing the professional standards, to controlling the performance of the undertaken obligations in both national and international legislation, to providing the opportunities for self-realization, as well as to promoting and protecting common interests.

In the majority of the $\mathrm{EU}$ member states in 8090 s of the last century there was a considerable growth in number of the registered non-commercial sector organizations, which now amount to 2 up to 3 million, and this figure does not take into account the non-official, non-registered associations, which are quite numerous in the above mentioned countries. The number of nongovernmental organizations is still increasing, and this trend is inseparable from the ideas of freedom and democracy, the guiding ideas for the Council of Europe and for the countries it includes.

The European Commission provides direct funding for the non-governmental organizations with more than 1 billion Euros annually. Of this amount 400 million Euros are allotted for the democracy development and human rights protection programs, for the crime prevention, social and educational programs within the $\mathrm{EU}^{32}$.

National efforts to coordinate NGOs and the police cooperation are supported by the EU. The European Commission provides assistance to multiple international European NGOs. Among those organizations are European Citizen Action Service (ECAS), European Council of Associations of General Interest (CEDAG), project TRIALOG ${ }^{33}$, which helps the Non-Governmental Organizations take part in the activities of the European NGO Confederation for Relief and Development.

In Great Britain the citizens are engaged to help the police on a voluntary basis. According to the plans of the government in this country the number of "voluntary guard" subdivisions should prospectively reach 5 million people which make a very impressive figure ${ }^{34}$. The volunteers of these subdivisions are in charge for patrolling and for searching the signals of crimes. They are not armed and they do not have any special uniform. Having learned about a crime, they just inform the direct action police department on duty about it by the radio. The suppression of crimes is not included in their functions ${ }^{35,36}$.

The major objective of the EU police cooperation is to guarantee the high level of personal protection for the European citizens ${ }^{37}$. To fulfill this, the Council of Europe envisaged wider cooperation between the police and the judicial authorities, and, to encourage the information flows on exchanging the up-to-date experience among the member states the European Crime Prevention Network (EUCPN) has been established.

The basis for boosting the crime prevention activities is represented by Items 29 and 30 of Treaty of Amsterdam, declaring that combating crime should be based not on repression only, but on prevention as well. Besides, Item 42 of the final meeting in Tampere recommends, in particular, that all EU members should coordinate their national efforts in this respect within the common EU framework.

The transatlantic cooperation in organizing the police activity on the whole and in exchanging the up-to-date police techniques is also a priority direction in the EU. Just within the period since November, 14, 2002 till May, 15, 2006 eleven meetings of Transatlantic round table on cooperation in security sector have been held. The need for transatlantic partnership and international cooperation occurred as soon as both the European Union and the USA were ready to jointly respond to the actions of international terrorism ${ }^{38}$. That is exactly why the decisions of the round tables were perceived and are perceived now by all the EU member states and the USA governments not as just recommendations, but as direct active guidelines to promote anti-terror activities in Europe and in the USA. Naturally, all this requires considerable financial investments. Therefore, the transatlantic cooperation includes non-governmental organizations and the private capital representatives, interested in preserving their transatlantic economic project investments safe and secure. As early as 2003 at one of the round tables a decision was made that the full security coordination program funding should be started in 2007, with the expected amount of funds up to two billion Euros annually through 2015, when the new financial plan for transatlantic security cooperation was supposed to be adopted.

The countries of Western-Europe came to understand the necessity for the collective crime combating about half a century ago. The first steps in the crime combating international cooperation were implemented within the framework of such regional organization as the Council of Europe. The need for cooperation in this sector was stipulated by the fact that European integration with its fundamental idea of freedom would lose any sense if this freedom could not cover the legal sphere. Historical and legal analysis affords identifying the following periods of establishing and developing the legal regulations and of 
the practice of European states cooperation in criminal court proceedings:

The European states cooperation in the above mentioned sector started within the framework of the Council of Europe, founded in 1949. Multiple agreements on combating crime were signed, a wide variety of international contracts in this sector were authorized. However, the lack of effectiveness in the Council of Europe legal and organizational mechanisms stimulated the European Community member states to start international cooperation in criminal court proceedings.

Several European countries reformed their criminal laws since 1970. Many of recently adopted criminal codes, notably, in Austria, France, Germany, Poland, Portugal and Spain have definite trends: In the general part they, as a rule, introduced the differentiating norms for criminal liability (for example, the differences within different forms of crime and the auxiliary liability, acceptance of legal error inevitability); those modern codes strive to limit the deprivation of liberty practice by means of involving, along with incarceration, the financial assets of a delinquent (fines, compensations) or his ability to be master of his free time (public works, arrest on holydays). Though the modern criminal laws within the European continent have many other common features, each country has its own style and methods for combating crime. Those different styles reflect the differences in politics, history and national culture. For instance, in some legal systems (Switzerland, the Netherlands) the short term imprisonment used to be considered as the main punishment for a medium-gravity crime, and it is still considered as such, whilst other countries (for example, Germany and Austria) have been trying to restrict the usage of this sanction, as far as it is believed to dissocialize a criminal. Since 1975 until 1993 lasted the period of the EU member states intergovernmental cooperation, when the cooperation in the criminal court proceedings sector was realized within the frameworks of specially created groups. It was exactly during this period that the prototypes of future European Union law-and-order organizations came to life, including such organizations as Europol, OLAF, as well as the auxiliary structures (European Information System, EIS). TREVI group, among other special working groups, used to act beyond the EU legal and institutional mechanisms. The supranational institutions did not possess independent competence in the crime and legal sector and could not issue regulatory acts. However, notwithstanding those restrictions, they made large contribution to developing the European states cooperation in the sector under discussion, and, most importantly, to developing the regulatory and legal basis for such cooperation.

Since 1993 until 1997, within the period in-between the Treaty of Maastricht and the Treaty of Amsterdam, the issues of the joint crime combating became an inseparable part of the new integration organization (European Union) competence area; those issues were granted their legal basis in Section VI of its founding agreement (Treaty of Maastricht). The issues of justice and of the internal affairs were structurally separated from the EU and other Communities; they became the object of the third independent "pillar" of the European Union. During this period the EU member states made mutually approved decisions on establishing the bodies authorized to implement the adopted projects (for example, the Convention based on Item K.3 of Treaty on European Union on establishing the European Police Office organization, Europol, on July, 26, 1995, concluded by the member states within the framework of the "third pillar").

1997-1999, the period opened by Treaty of Amsterdam, consolidated the profound reform of the third EU "pillar", "Cooperation in the sector of justice and home affairs", which resulted in formalizing the unified bases of the EU common criminal policy and was focused on establishing "European space of freedom, security and justice".

Then followed the period, which started after the EU summit in Tampere (1999), aimed at achieving the agreement on the ways to implement Treaty of Amsterdam, determining the strategic directions for creating "European space of freedom, security and justice", as well as at solving other concrete issues of the EU institutions.

The period, which started with the Treaty of Lisbon becoming effective (December, 1, 2009), is characterized by the fact that the EU granted to its citizens "the space of freedom, security and justice" without any internal borders, which is ensured, among other means, by mutual acceptance of the criminal court decisions, and, if required, by the approximation of criminal laws. Within this period the legal bases for arranging the EU bodies and organizations activity in the sector of the criminal court proceedings have been directly consolidated in the "new" EU founding documents and have started to be regulated by the institutional part of its $\operatorname{law}^{40}$.

Thus, it is necessary to consider the individual features 
of each separate country in order to comprehend the European legal reform in full.

The Supreme Court of Germany has been for several times maintaining that the punishment needs be determined; this is in conformity with the Constitution, with the principles of a law-governed state and with the criminal law principle of the personal and of the faultbased liability. The reforms of German criminal legislation in 60-80s of the 20th century have been influenced by the ideas of the criminal law sociological school, which could not help being reflected in redistributing the competence between the legislator and the judge in the course of determining the punishment within the law and in practice. In criminal law practice the accent has shifted from the general prevention through a rightful retribution to individual prevention and to the re-socialization of the criminal. Thus, in German criminal law the trend of limiting the judge's discretion by the legislator has been observed over the recent years. In a number of other states the legislator delegates some of his competences to the judge, thus hardly making any differentiation in criminal liability.

Penal Code in France, in case of repeated commission of an offence, and the Law of competency in a criminal case of 1973 in Great Britain, applied to "conventional criminals" ( $\$ 28)$, stipulate the reduplication of the maximum term of imprisonment. Also typical is the gradual reduction in punishing juvenile criminals, as a rule, by half (Penal Code of France). Similar stipulations are included in criminal laws in some East-European countries.

Modern criminal policy in Italy represents the realization of the criminal and legal ideas of different schools and trends, in the first place, those of the classical and of sociological schools of law. In contemporary Italian criminal law the ideas of both classical sociological (positivist) schools have been reflected. Thus, Item 1 of Penal Code of Italy formulates the principle nullum crimen nulla poena sine lege (no crime, no punishment without a previous penal law), Item 42 of the Penal Code states the liability of the guilty, which is characteristic for the classic school of the criminal law. At the same time Italian Penal Code abides by the dualistic system of the criminal responsibility realization, namely, by applying punishment or security measures or both. As is well known, Italy was the founder of three scientific schools in the sphere of criminal law: Enlightening-humanistic, biopsychological and sociological. They all have been reflected, to a different degree, in the current Penal Code of Italy. Obviously, the historical priority in developing the scientific schools of criminal law made Italian legal system more conservative, if compared to such countries with the continental legal systems as France and Spain.

Considering social changes, affecting crime in Europe, the major ones should be noted, that is the changes in the legal system and in the crime policy, including both new postulates of the criminal law, and the changes in the practice of criminal justice, especially, in the police forces. The success of the criminal policy is explained not by strengthening criminal repression, but by applying all means of the social control available within the community.

When selecting the means, a general rule should be observed: If it is possible to solve the task with minimum restrictions to the interests of the citizens, then the harder means should not be applied. Due to this, it becomes possible to keep crime at a comparatively low level. It should also be highlighted that this option of the criminal policy is, to a great extent, realistic, because the European traditional community does preserve the potential for the traditional (informal) control over crime. The essence of the crime policy, implemented in modern Europe, consists of preventing the crimes, both primary and the repeated ones, deploying close cooperation of the law-and-order authorities with the wide circles of the population. This is in conformity with the crime policy, implemented by the authorities and supported by all spectrum of the civil society.

Considerable success has been achieved in the sphere of re-socializing the criminals. In order to prevent repetitive crimes, there is a general intention in Europe to avoid any unnecessary "labeling" of the persons, who trespassed against the law, so that they would not acquire the "outcast" complex.

The Council of Europe, including the representatives of almost all of the European states, acts a very important part in establishing the unified standards of criminal justice and in facilitating the cooperation in transnational legal actions. The most important European tool in this sphere is Convention for the Protection of Human Rights and Fundamental Freedoms of 1950 (ECHR), which was signed and ratified by all participants of the Council of Europe. The Convention guarantees to the citizens a number of important principal rights, directly associated with criminal proceedings, such as prohibition of torture and cruel punishment. The European Court of Human Rights in Strasburg is the custodian of human rights according to the Convention, and any citizen, upon having 
exhausted the means of legal protection within the home law, can lodge a complaint against its state, if it violates even one of the rights, guaranteed by the Convention. The decisions of the court affected the laws of the EU member states considerably.

The documents of the Council of Europe used to be and still are the source for several conventions on cooperation in criminal prosecution and in execution of punishment, as well as for multiple recommendations on crime policy in European states.

\section{Conclusion}

- The governing institutions of the European Union work on creating the "Europe for citizens", where the Non-Governmental Organizations come to solidarity, where the new forms of social partnership emerge. Keeping abreast with the times the EU started applying the strategic planning in different sectors, including social sphere and crime, especially transnational crime, combating sector.

- In the short-term prospective the reorganization of the EU economics will facilitate solving almost all other problems which exist in Europe. The same trends, which lead to interdependency of the European countries, are, at the same time, the trends, which lead to dissention. It appears that the federal system of the EU, supported by wider legitimacy and stronger ability to lead other countries of the European Union, is the only possible step forward in many spheres, including crime prevention, public security and personal freedom protection of the citizens.

- The process of uniting Europe, which started after the Second World War and acquired new dimensions upon finishing the political division of the continent in the 1990s, has now encompassed the criminal law, though not to such an extent as it did in the private law.

- The main objective of the police cooperation in the EU countries is to guarantee the high level of personal protection for European citizens.

\section{References}

1. Klockars C. The idea of police. London; 1985.

2. Leonard V. The police organization and management. Springfield; 1969.

3. Goessner R, Herzog H. In the shade of law. Methods of the new secret police. Moscow; 1994.

4. Bittner E. Police charge. Oxford; 1980.

5. Hauer VD. Police in Western Europe. Bonn; 1992.
6. Hietaniemi T. 75 Years of national police training. Helsinki; 1995.

7. Schulte R, editor. 50 Jahre Polizeische Bildungsarbeit in Mtinster-Hiltrup. Munister; 1997.

8. Anderson A. Police. Copenhagen,;1985.

9. Bonell MI. Legal studies in today's Europe: Towards a European lawyers? American Journal of Comparative Law. 1993; 41(3).

10. Elsdon KT. Training for adult education. London; 1983.

11. Hebenton B, Thomas T. Policing Europe: Cooperation, control and conflict. Basingstoke; 1995.

12. Walker SA. Critical history of police reform. Lexington; 1977.

13. Bittner Egon. The function of police in modern Society. Cambridge; 1980 etc.

14. Berg BL. Law enforcement: An introduction to police in society. Boston; 1991.

15. Kargalova MV. Social Europe in the 21st century. Part 1. Social core of Europe. Reports of Institute of Europe. Moscow. 2009; 246:2-4, 86-99.

16. Nicolas A. Black in blue: A study of Negro policemen. NewYork; 1969.

17. Carter DL. Hispanic perception of police performance: An empirical assessment. Journal of Criminal Justice. 1985; 13.

18. Harris RN. The police academy: An inside view. New-York; 1973.

19. Heffnerman W, Stroup T. Police ethics: Hard choice in law enforcement. New-York; 1985.

20. Hochstedler E, Conley JA. Explaining under-representation of black officers in city police agencies. Journal of Criminal Justice. 1986; 14.

21. Jacobs J, Cohen J. The impact of racial integration on the police. Journal of Police Science and Administration. 1978; 6.

22. Kuykendall JL, Burns DE. The black police officer: An historical perspective. Journal of Contemporary Criminal Justice. $1980 ; 1$.

23. International police cooperation. A world perspective. In: Koenig DJ, Das DK, editors. Lanham; 2001.

24. Mavby RI. Comparative research police practices in England, Germany, Poland and Hungary. Policing in Central and Eastern Europe. Ljubljana; 1996.

25. Perlstein GR. Policewomen and policemen: A comparative look. Police Chief. 1972; 39(3).

26. European Security and Defense Policy External relations. Official Journal of the European Union (EN) No. L 212/19. 27.4. 2009.

27. Nenad M. The development of an educational culture in border police organizations. Ljubljana. 2008; 2.

28. Treaty of Amsterdam amending the Treaty on European Union, the European Community Treaties and some Acts related thereto. Section 5. Guidelines on common security and Defense Policy External relations. Item J7.4. Documents of European Union. Moscow; 1997.

29. Documents of European Union. 5. 1-4. Moscow; 1997.

30. Derbicheva SA, Astapenko PN. Institutional evolution of 
the internal affairs authorities and the problems of optimizing the police knowledge. Moscow; 2007. p. 118.

31. Howell Beryl A. Proving web history. Journal of Internet Law. 2006 Feb; 3-9.

32. Guiding principles of non-governmental organizations status in Europe and explanatory note. Decision of the Committee of Ministers of European Union. Strasburg; 2002 Nov 13. Meeting 837, 2003 Apr 16. Strasburg; 2003.

33. Waddington PAJ. Policing citizens: Authority and rights. London. 1999; 145-65.

34. The National plan for development of police in 2005-2008 years. L; 2005.

35. Chan JBL. Changing police culture: Policing in a multicultural society. Cambridge; 1997.

36. Smith D. Police and people in London. London. 1983; $14: 100-3$.
37. Documents of European Union. 5. 1-4. Consolidated version of European Union Treaty and European Community Treaty. Moscow. 2001; 27-8.

38. Commission on crime prevention and criminal justice. 12th session. Vein; 2003 May 13-22.

39. Item 4 of the preliminary agenda: Activities of the International Crime Prevention Centre; activities of the UN Program institutes network in crime prevention and criminal justice. Report by General Secretary. Vein; 2003.

40. Damirchev EI. European Union Member States cooperation in the sphere of criminal procedure. Theoretical and practical aspects [Synopsys of thesis of applicant for a degree of candidate of Law Sciences]. Moscow; 2011. 